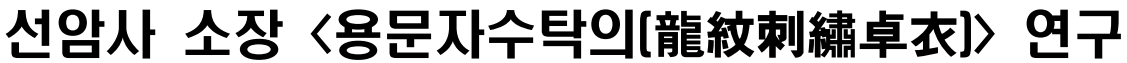

\author{
심 연 옥 \\ 한국전통문화대학교 전통미술공예학과 부교수
}

\section{Study on 〈Embroidered Tak Ui with Dragon Pattern〉 Housed at Museum of Sun Am Temple}

\author{
Sim Yeon-Ok \\ Associate Professor, Dept. of Art and Craft, korea National University of Cultural Heritage \\ (received date: 2016. 12. 28, revised date: 2017. 2. 6, accepted date: 2017. 2. 13)
}

\begin{abstract}
This study is for the textiles of <Embroidered Tak Ui with Dragon Pattern $>$ at Sun Am Temple and characteristic of embroidery. Tak $U i$ was composed of orange body and green upper cover, and had no strings. The body plate was covered with embroidery, with Gauze base, and upper part was appliqued, by cutting dragon pattern, cloud pattern on satin damask. The thread for embroidery was silk floss, silk twisted thread, rapped gold thread, and rapped silk thread. For padding, it was used cotton thread in the part of dragon's scales. It was used satin stitch, outline stitch, split stitch, couching, and counted stitch, etc. as method of embroidery. In particular, it embroidered counted stitch of diamond shape consecutively on the whole of Tak $U i$, it does so with counted stitch of same effect of weaving Brocade in the part of cloud. Besides, it is one of the characteristic for couching rapped silk thread. Such lead embroidery is the popular method in the Ming dynasty of China, in the 16 17 century. The design of Tak $U_{i}$ is dragon, cloud, and wave in the theme. In the center, 'Seong-su-man-nyeon' was placed on the heads of dragon. This is similar to Dragon Robe of Four-petalled medallion patterns, period of Ming dynasty in China. Therefore, it confirmed that Tak $U_{i}$ was remodeled the embroidered textiles, made for royal robe, originally, with Tak $U i$ at temple.
\end{abstract}

Key words: counted stitch(납사수), embroidery(자수), gauze(사), satin damask(문단), $T a k ~ U i$ (탁의)

이 논문은 「2016년도 한국전통문화대학교 학술연구지원 사업」의 지원을 받아 수행된 연구임.

Corresponding author: Sim Yeon-Ok, e-mail: sim-yeonok@hanmail.net 


\section{I. 서론}

순천 선암사(仙嚴寺) 성보박물관에 소장된〈용 문자수탁의(龍紋刺䋓卓衣) $>1)$ 는 삼보명자수가사(三

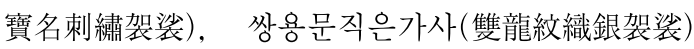
와 함께 중요민속문화재 제244호로 지정되어 있 다. 탁의는 몸판 전체가 자수로 조성되었으며, 특 별한 자수기법과 다채한 색채구성으로 그 가치가 높이 평가되고 있다.

탁의는 왕실이나 사찰에서 의식을 행할 때 상 위 를 덮거나 옆으로 쳐서 두르던 중요한 장엄구이다. 『숙종실록』30권 1696년 11월의 기록에 “삼언 등은 체종이 불탁의(佛卓衣)를 훔쳤는데, 저희들에게 발 각되자 이렇게 거짓으로 끌어대었다 하였다(三彥等 以㥯: 體宗偷佛卓衣, 爲渠輩所覺, 有此誣引)”는 내 용을 통해 사찰에서 쓰는 탁의는 '불탁의(佛卓衣)' 라고 하였으며, 통도사 소장 용문탁의에도 '탁의(卓 衣)'라는 명문이 묵서된 것을 확인할 수 있다.

현재 우리나라에 남아있는 탁의유물은 순천 선 암사 소장 자수탁의 1점, 통도사 성보박물관 소장 의 대웅전(大雄殿) 용문탁의와 관음전(觀音殿) 직 금탁의 등이 있으며, 선운사에도 1점이 남아있는 것으로 알려져 있다.

탁의의 재료는 용포(龍袍)용 직성류 직물이나 직금단 등 모두 당대 최고의 직물로 제작되어 탁 의가 장엄용으로 매우 중요한 의미가 있었음을 알 수 있다. 특히 선암사 용문자수탁의는 전체가 자 수로 만들어진 유일한 작품으로 불교 장엄구에 대 한 연구뿐만 아니라 자수연구에 있어서도 중요한 자료적 가치가 있다. 우리나라에 남아있는 자수유 물은 대부분 조선말기와 근대에 집중되어 있고 이 른 시기의 유물은 매우 제한적으로 남아있어 그 가치가 더욱 크다.

탁의는 일부가 탈락되고 헤어진 부분이 있으나 보수처리를 거쳐 현재의 상태는 양호한 편이며 각 색 자수사와 금사 등이 아직도 선명하게 남아 있다.

1) 이하에서는 탁의로 약칭함
용문탁의는 중요한 자수유물임에도 불구하고 현재 까지 간단한 문화재 지정 보고서와 불탁연구(Heo, 2004)에서 일부 다루었을 뿐 자수공예와 섬유학적 측면에서의 상세한 분석과 연구는 전무하다.

본고에서는 용문탁의에 대한 섬유조사와 분석을 통하여 다음과 같은 측면에서 탁의가 갖는 섬유공 예 기술적 특징과 가치에 대해서 논하고자 한다.

첫째, 탁의의 구성특징을 살펴보고, 탁의에 사 용된 직물의 제직특성에 대해 분석하였다.

둘째, 용문탁의에 시문된 자수기법과 표현 특징 을 분석하고, 유사한 기법의 자수유물과 비교하여 시대적 특징을 판단하였다.

셋째, 문양의 종류와 구성특징을 분석하고 탁의 직물의 용도 및 탁의제작시기를 유추해보았다.

유물 조사도구는 디지털카메라와 포터블 디지 털현미경 DG-3x를 사용하였다.

\section{II. 탁의의 구성과 직물}

\section{1. 탁의의 구성특징}

탁의(卓衣)는 명칭에서 뜻하듯이 탁자를 덮거 나 가리는 용도의 장엄구로 사찰에서는 야외의식 때나 실내 불탁을 가릴 때 사용된다. 탁의를 장엄 한 도상은 고려불화를 비롯한 조선시대 탱화에서 다양한 형태로 나타난다.

〈Fig. 1〉은 일본의 약선사(藥仙寺)에 소장된 조 선 16 세기 감로탱으로 공양물이 차려진 제단은 탁 의가 세면을 둘러싸고 있으며, 구성은 하단의 몸판 과 상단덮개의 구조에 영자가 달린 형식이다. 상단 의 덮개가 바람에 날리는 표현으로 보아 상단은 하단 위로 덮는 이중형태로 제작되었음을 짐작할 수 있다. 탁의의 몸판 색은 홍색이고 상단덮개는 녹색으로 대비되는 색을 사용하였다. 〈Fig. 2〉는 통도사에 소장된 관음전 탁의로 녹색 직금단 몸판 에 홍색 직금단 상단덮개와 영자를 갖추고 있다.

용문자수탁의〈Fig. 3〉의 형태는 장방형으로 전 체크기는 가로 $365.5 \mathrm{~cm}$, 세로는 $115 \mathrm{~cm}$ 정도이다. 


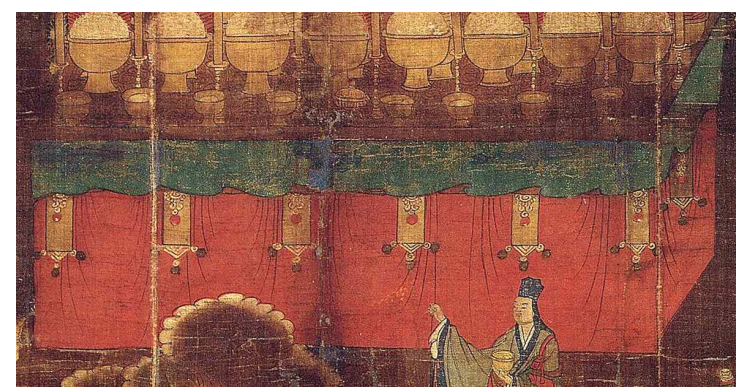

〈Fig. 1〉 Tak Ui of Nectar Ritual Painting, Yakusen-zi, Japan (Kang \& Kim, 2010, p. 24)

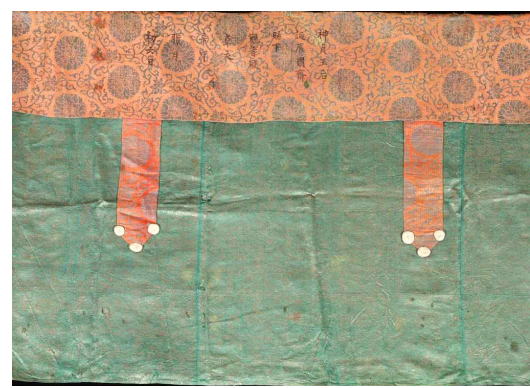

〈Fig. 2〉 Tak Ui of Tong Do Sa, Gwaneumjeon

(Photography by Researcher)

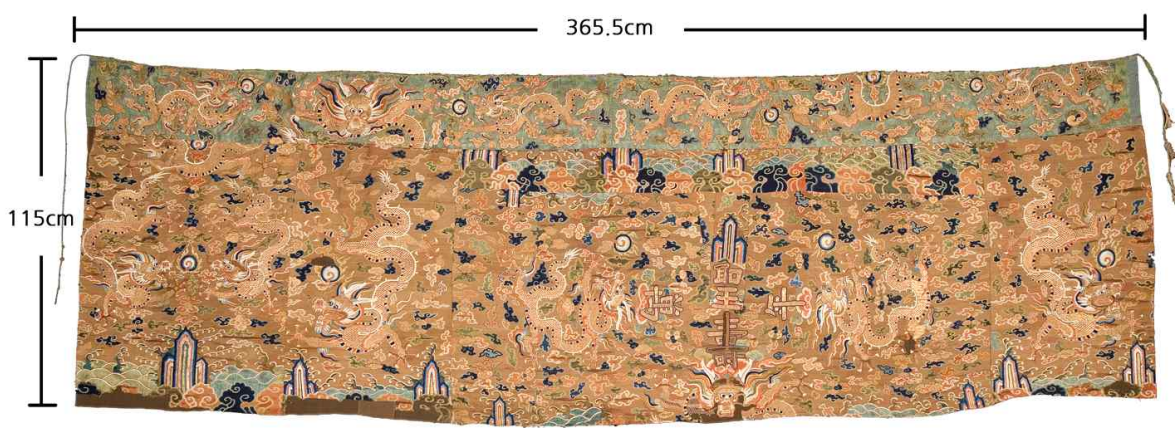

〈Fig. 3〉 Embroidered Tak Ui with Dragon Pattern Housed at Museum of Sun Am Temple (Photography by Researcher)

탁의는 하단의 몸판과 상단덮개로 구성되어 있다. 몸판은 현재 황갈색이나 안쪽에 퇴색이 덜 진행된 부분의 실이 붉은색을 띠고 있는 것으로 미루어 원래 홍색이었을 것으로 추정된다. 상단은 하단 몸판과 대비되는 녹색을 사용하여 불화에서 보이 는 탁의의 형식을 따르고 있다. 상단은 몸판 위로 덮는 구성이 아니라 하단 몸판과 붙여서 바느질하 여 한판을 이루고 있으며, 영자도 달려있지 않아 불화나 통도사 유물에서 보이는 탁의 구성과는 차 이가 있다. 상단의 길이는 $23 \mathrm{~cm}$, 하단 몸판의 길 이는 $92 \mathrm{~cm}$ 이다. 몸판은 모두 5 폭을 이어서 만들었 으며 각각의 폭 너비는 바라보는 좌측부터 $68 \mathrm{~cm}$, $56 \mathrm{~cm}, 93 \mathrm{~cm}, 90.5 \mathrm{~cm}, 55.5 \mathrm{~cm}$ 이다. 성수만년(聖壽 萬年)의 명문이 자수된 부분은 겉으로는 전면에 자수가 놓여 한판처럼 보이나 하단 자수가 훼손된
부분에 식서와 식서를 맞대고 휘갑치기하여 폭을 이은 부분이 확인된다.

상단은 세로 $23 \mathrm{~cm}$ 너비로 좁고 긴 띠 형태이며 가로의 길이 방향으로 $174 . \mathrm{cm}$ 와 $175.3 \mathrm{~cm}$ 로 재단된 두 조각을 이어서 구성하였다. 상단 맨 위의 끝부 분은 $0.7 \mathrm{~cm}$ 너비로 시접을 안으로 접어 면사로 홈 질하여 긴 통로를 만들고, 그 안에 굵은 오색의 면 사를 끼워 넣었다. 면사의 두께는 $0.36 \mathrm{~cm}$ 이며 단사 여러 올을 좌연으로 합사하였다. 오색사는 좌우 각 각 $87 \mathrm{~cm}, 59 \mathrm{~cm}$ 정도 밖으로 빠져 있다.

\section{2. 탁의의 직물}

탁의 하단몸판의 자수 바탕직물은 소사(素紗) 〈Fig. 4〉, 즉 무늬가 없는 무문사(無紋紗)를 사용 


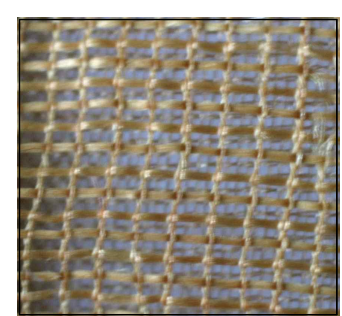

〈Fig. 4〉 Simple Gauze (Photography by Researcher)

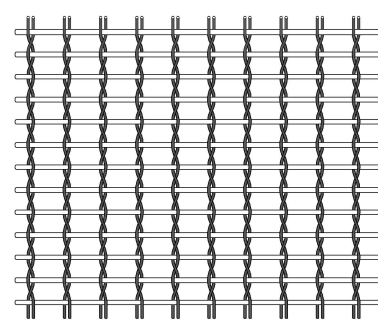

〈Fig. 5〉 Diagram of Simple Gauze

(Illustration by Researcher)

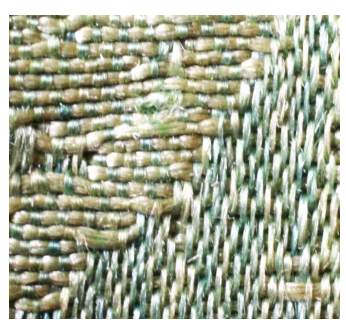

〈Fig. 6〉 5-end Satin Damask

(Photography by Researcher)

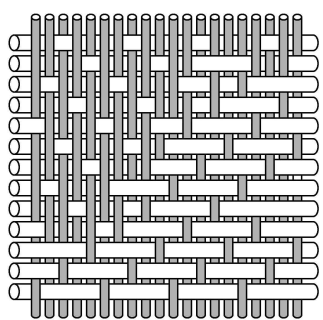

〈Fig. 7〉 Diagram of 5-end Satin Damask (Illustration by Researcher)
하였다. 소사는 2경꼬임 사직물로 꼬임경사 1올, 지경사 1 올이 한 조가 되어 제직되는 단순 꼬임직 물이다(Sim, 2002, p. 180). 2경 꼬임 사직물은 고 려 후기의 불복장물에서 처음 보인다. 사직물이 자 수에 사용되는 경우는 많지 않으며 16 17세기 납 사수라고 하는 기법의 자수에 사용된 예가 보인다.

〈Fig. 5〉의 조직모형도에서와 같이 사조직은 경 사 2올이 함께 꼬이기 때문에 경사가 몰리면서 조 직과 조직 사이가 벌어져 명확한 방형의 구멍이 생긴다. 따라서 직조와 같이 규칙적으로 올을 세 며 한 땀씩 놓는 자수에 적합한 직물이다. 탁의의 경사는 가는 실을 사용하고 밀도는 $1 \mathrm{~cm}$ 당 약 28 올 정도이며, 위사는 경사보다 굵고, 밀도는 $1 \mathrm{~cm}$ 당 약 21 23올 정도이다.

상단은 녹색운보문단직물을 사용하였으며 조직 은 5 매 2뜀의 경수자조직에 5 매 위수자조직으로 무늬를 짠 단층의 문조직이다〈Fig. 6, 7〉.

\section{III. 자수의 기법과 특징}

\section{1. 자수사의 종류와 색}

용문자수탁의에는 다양한 종류의 실을 사용하여 자수에 변화와 입체감을 더하였다. 사용된 실을 형 태와 재료별로 분류하면 꼰사, 푼사, 연금사(撚金 絲) 연채사(撚彩絲), 면사(綿絲) 등이다〈Table 1〉. 자수의 바탕을 메우고 있는 마름모형의 납사수와
운문 납사수는 모두 굵은 꼰사를 사용하였다. 우연 으로 약하게 꼬임을 준 실 2올을 합쳐 좌연으로 강한 꼬임을 주었다(Type1). 푼사는 납사수를 제 외한 파도, 영지, 용의 부분, 강애해수문 등을 표현 한 평수에 사용되었다(Type2). 연금사는 용의 몸 통과 구름의 운두부분에 사용하였다(Type3). 연금 사는 방추차의 회전력을 이용해 심사에 편금사를 말아 감아 만든 금사를 말한다( $\operatorname{Sim}, 2013$, p. 83). 편금사는 종이를 배면으로 하여 금박을 붙인 지금 (紙金)의 형태로, 금박이 떨어진 부분에는 붉은색 접착제의 흔적이 남아있다. 연채사는 소색의 좌연 견 꼰사를 심사로 하여 그 위에 견 푼사를 말아 감아 만들었다(Type4). 감는 푼사의 색을 달리하 여 매우 다채롭게 표현하였으며, 광택이 많이 나서 다양한 장식적 효과를 나타낼 수 있다.

자수에는 모두 견사가 쓰였지만 용의 비늘부분에 속수를 놓기 위해 면사를 사용하였다. 우연의 면사 2올을 좌연으로 약하게 꼬아 합사하였다(Type5).

탁의는 오랜 세월 외부에 노출됨으로서 자외선 과 대기의 환경에 의해 열화되고 퇴색되었다. 바 탕의 마름모형 납사수의 색은 현재 황갈색을 나타 내고 있으나 밖으로 노출되지 않은 뒷면 자수사의 색이 홍색인 것으로 미루어 원래 탁의의 바탕색은 홍색이었을 것으로 추정된다. 자수는 다양한 계열 의 색 약 20 여종을 사용하였다. 색상을 계통별로 구분해 보면 홍색계열의 홍 - 주황, 청색계열의 아 
〈Table 1〉 Types of Threads Used for Embroidery

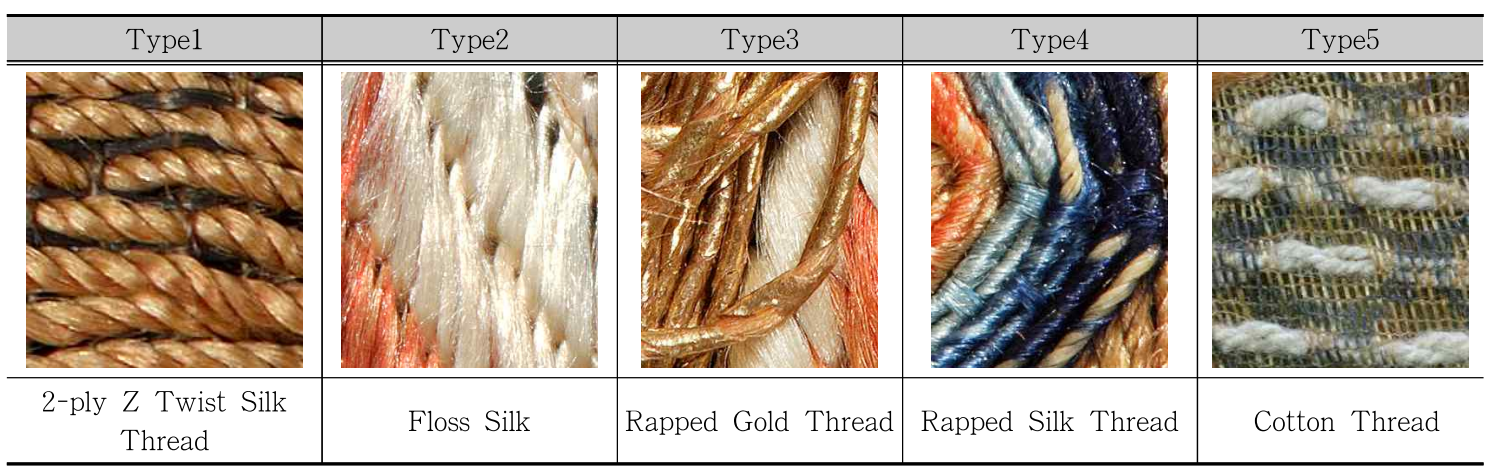

(Photography by Researcher)

청 - 청 · 천청, 녹색계열의 녹 · 두록 - 연두 · 청녹, 황색계열은 황 - 갈색 · 연갈색 · 황갈색 · 미황색 등 이 있으며 그 외 백색이 많이 사용되었다. 특히 구름은 꼰사를 사용하여 3 4가지 색으로 테두리 를 둘러 오색구름에 입체감을 더하였다.

\section{2. 자수기법 및 특징}

\section{1) 납사수(納紗紼)}

탁의의 바탕은 꼰사를 사용하여 마름모무늬와 구름무늬를 납사수로 표현하였다. 납사수는 착사

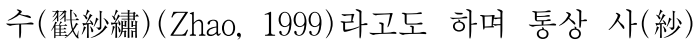
를 바탕직물로 사용하여 수 땀을 규칙적으로 놓아 마치 직조와 같은 표현을 하는 자수기법이다. 사
직물은 짜임이 성글기 때문에 올을 세기가 용이하 여 반복되는 규칙적인 무늬를 표현할 수 있다. 탁 의에는 두 종류의 납사수가 사용되었으며, 모두 표면수 즉, 홑수로 표현되었다.

첫 번째 유형은 탁의 바탕 전체에 표현된 납사 수로서 마름모무늬가 직물 전면에 규칙적으로 연 속되어 마치 직조한 문직물과 같다. 수는 바탕직 물의 위사와 위사 사이에 일정하게 가로방향으로 놓여 지며, 규칙적으로 경사를 한 땀씩 떠서 연속 된 마름모를 형성하였다. 마름모무늬가 끝나는 지 점에서 자수사는 다시 반대방향으로 돌아가며 자 수하여 마치 직조의 장화기법과 같다〈Fig. 8〉. 〈Fig. 9〉와 같이 뒷면에서는 한 땀씩 뜬 자수사만 이 확인된다. 〈Fig. 10〉은 사직물에 자수된 마름모

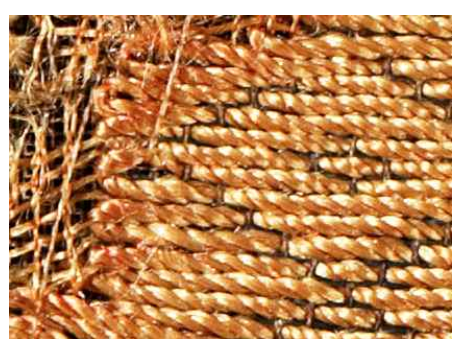

〈Fig. 8〉 Napssa - su Type 1 Front Side

(Photography by Researcher)

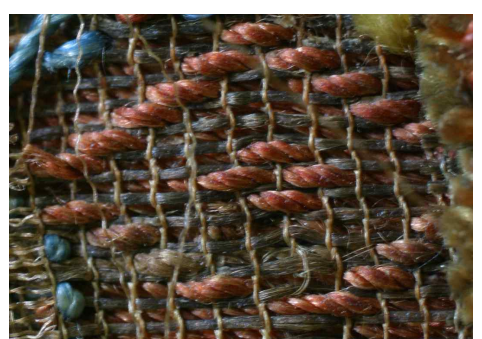

〈Fig. 9〉 Napssa - su Type 1, Back Side

(Illustration by Researcher)

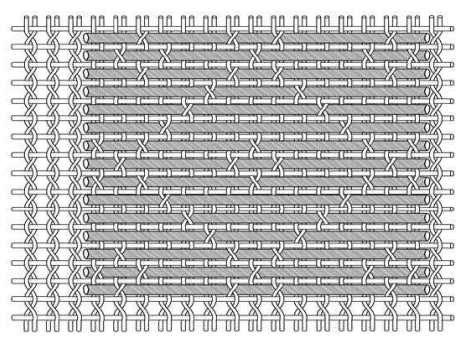

〈Fig. 10〉 Diagram of Napssa - su Type 1 
형 납사수의 모형도이다.

두 번째 유형은 마름모와 같은 특정무늬를 표 현하지 않고 면을 메우면서 규칙적인 조직점을 표 현한 유형이다. 구름과 하단의 입수(立水)형태의 파도무늬에서 보인다〈fig. 11〉. 자수사는 마름모형 납사수와 같은 꼰사를 사용하였으나 각종 다채한 색으로 자유롭게 표현하였다. 자수사는 바탕직물 의 위사와 위사 사이에 가로로 일정하게 놓여 지 며, 규칙적으로 경사를 한 땀씩 떠서 마치 직물의 조직점과 같이 표현하였다〈Fig. 12〉. 자수사는 무 늬가 끝나는 지점에서 다시 반대방향으로 돌아가 며 자수하여 마치 직조의 장화기법과 같다〈Fig. $13\rangle$. 즉, 지위사 한 번에 문위사 한 번을 직조하는 부가문위사 위중조직과 같은 형식이다. 조직점은 직조의 8매 3뜀과 흡사하나 이시기는 아직 8매수
자조직이 나타나지 않기 때문에 임의로 만들어진 자수 땀임을 알 수 있다. 구름 가장자리는 짧은 땀으로 표현하였기 때문에 조직점을 두지 않았다.

현재까지 이 같은 자수에 대한 분류나 정확한 명명은 없었다. 필자는 이 자수가 사조직을 바탕 으로 사용하고, 마름모형 납사수와 같이 표면수이 며, 올을 세며 규칙적인 조직점을 표현한 부분이 동일하기 때문에 납사수의 유형으로 분류하였다.

\section{2) 평수}

납사수 부분을 제외한 용, 수파 등 주제문양의 대부분은 평수로 표현되었다. 평수는 모두 푼사를 사용하여 바탕의 꼰사 질감과 다른 표현을 만들었 다. 평수는 대부분 붙임수의 기법을 사용하여 여러 단을 순차적으로 표현하였다. 앞서 놓은 평수 위에

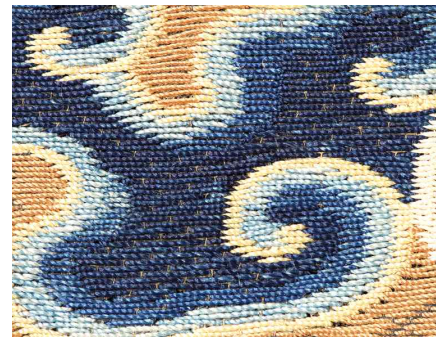

〈Fig. 11〉Napssa-su Type 2 (Photography by Researcher)

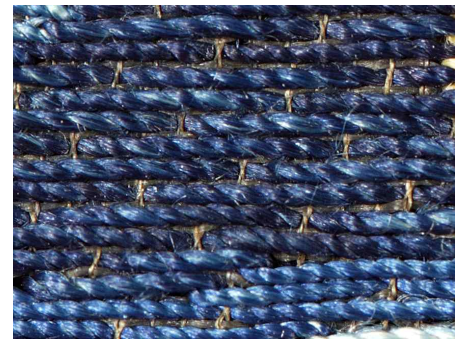

〈Fig. 12〉 Napssa-su Type 2 Detail (Illustration by Researcher)

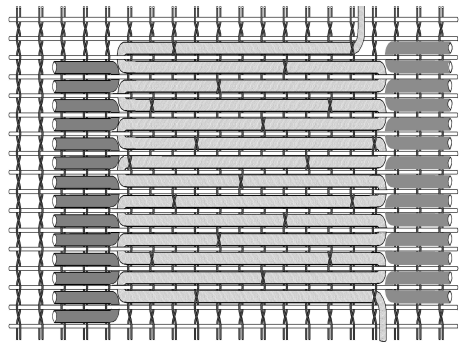

〈Fig. 13〉 Diagram of Napssa - Su Type 2

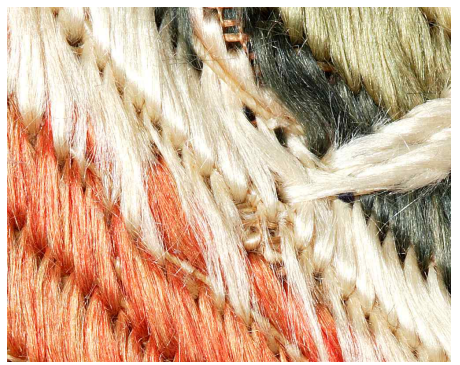

〈Fig. 14〉 Satin Stitch (Photography by Researcher)

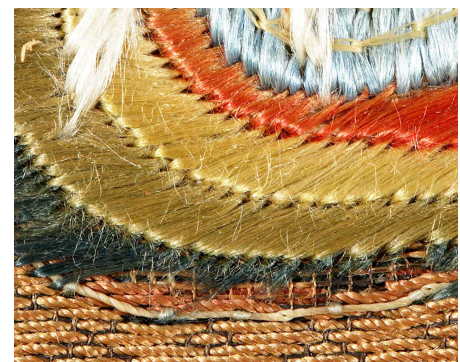

〈Fig. 15〉 Satin Stitch (Photography by Researcher)

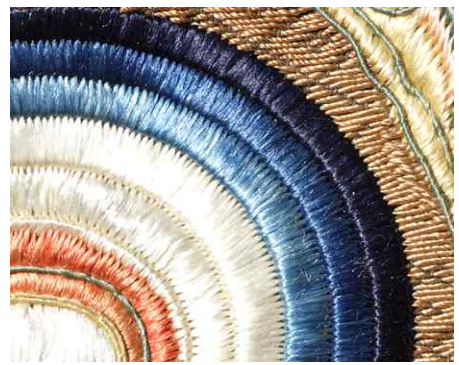

〈Fig. 16〉 Satin Stitch (Photography by Researcher) 
속수용 심사를 징그고 그 위로 평수를 겹쳐 놓는 형식〈Fig. 14〉의 붙임수로 대부분 짧은 땀을 사용 하였다. 용의 갈기 부분은 사선평수를 겹쳐가며 여 러 가지 색을 배색하여 섬세하면서도 다채하게 표 현하였다〈Fig. 15〉. 여의주는 홍, 황백, 백, 천청, 청, 아청색의 수직평수를 방사형으로 전개시켜 입 체화 시켰다〈Fig. 16〉. 용의 몸통 안쪽부분은 아청, 청, 황, 백, 홍색을 붙임수로 자수하여 띠처럼 둘렀 는데 색동의 배색이 용의 생동감을 더한다.

평수는 대부분 표면평수로 이루어져 있다. 표면 평수는 뒷면에 놓이는 실을 최소화하여 실의 낭비 를 줄이고 부피를 적게 하는 효과적인 방법이다 (Sim, 2013).

\section{3) 이음수 · 가름이음수}

탁의에서 이음수는 극히 일부에만 사용되었다. 용의 몸통 안쪽에 띠처럼 두른 색동으로 놓은 평 수 가장자리에 한 쪽은 연채사를 징거 두르고, 반 대쪽은 백색푼사를 사용해 이음수〈Fig. 17〉로 선 을 둘러 경계를 표시하였다.

용의 발과 수파부분에 표현된 자수 중에는 마 치 사슬수와 같은 형태의 자수가 있다. 그러나 자 세히 관찰해 보면 사슬수가 아니라 이음수와 유사 한 자수기법임이 확인된다. 이음수에서는 선과 선 이 일부 빗겨서 겹쳐지며 연속되지만 이 자수는 선의 일부가 포개지면서 겹쳐 연속된다. 수를 놓
는 방법은 선을 한 땀 짧게 놓고 다시 수를 놓을 때 먼저 놓은 수 땀의 끝부분으로 바늘을 되돌려 실의 중앙을 통과해 올라온다. 이때 먼저 놓은 실 이 갈라지면서 사슬과 같이 표현되는 기법이다.

이와 같은 기법은 서양자수에서는 '스플릿 스티 치(Split Stitch)'라고 하며 중국에서는 '벽수(䢃 緟)'라고 하나 우리나라에서는 이 자수기법에 대 한 명명을 찾을 수 없다. 따라서 필자는 이 자수 법을 '가름이음수'라고 가칭하였다.

탁의에 표현된 가름이음수는 먼저 푼사로 평수 를 길게 놓은 표면 위에 수를 놓아 긴땀을 눌러주 는 역할과 더불어 장식적인 효과를 나타내었다. 용 에 표현된 가름이음수는 둥글게 돌아가는 원을 생 동감있게 표현하였다〈Fig. 18〉. 짧은 땀으로 놓아 사슬수와 구분하기 어려울 정도다. 〈Fig. 19〉와 같 이 파도의 물결부분은 청색 푼사로 평수를 긴땀으 로 놓아 면을 메운 다음 붉은색, 황색의 푼사로 가 름이음수를 길게 연속해 놓아 물결의 잔잔함을 율 동적으로 표현하였다. 아랫단과 윗단의 사슬방향이 반대로 나타나 수를 놓을 때 왼쪽에서 오른쪽, 오 른쪽에서 왼쪽으로 진행하였음을 알 수 있다.

\section{4) 징금수}

징금기법은 징그는 실의 재료에 따라 금사징금 수와 연채사징금수로 분류된다. 금사징금수는 용 면(龍面)과 운두(雲頭) 부분의 면을 메우는 용도

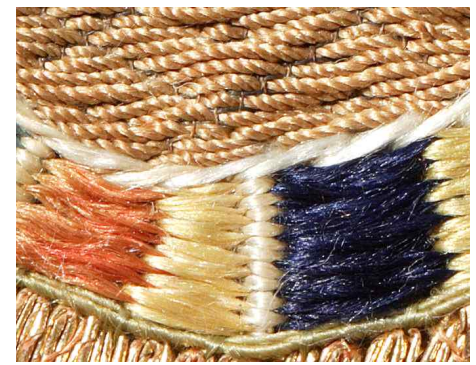

〈Fig. 17〉 Outline Stitch (Photography by Researcher)

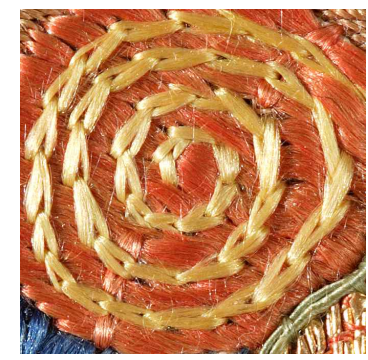

〈Fig. 18〉 Split Stitch (Photography by Researcher)

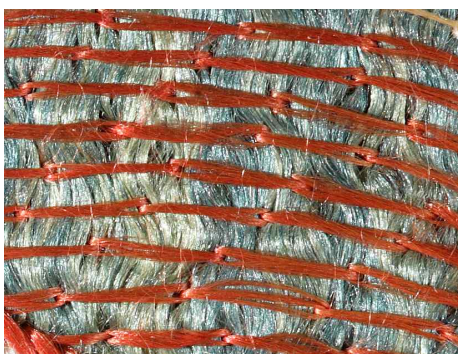

〈Fig. 19〉 Split Stitch (Photography by Researcher) 
로 사용되었다. 연금사는 2 올을 함께 나란히 사용 하여 황색견사로 징겄다. 성수만년 글씨부분은 중 심부터 방사형으로 말아가며 징금하였다〈Fig. 20〉.

연채사는 구름, 용, 문자 등의 가장자리에 징거 둘러 장식하였으며, 긴 땀의 평수 위에 올려 부분장 식의 효과로도 사용되었다. 특히 성수만년의 글자부 분은 연금사로 자수한 후 가장자리에 홍색, 천청색, 청색, 아청색의 연채사를 2 올씩 징거서 둘러 문양을 두드러지게 강조하였다. 징그는 실은 연채사와 같은 색을 사용하여 징근 부분이 잘 드러나지 않아 색사 가 더 선명하게 드러난다〈Fig. 21〉. 또한 〈Fig. 22〉 와 같이 평수의 속수용 심사로 사용하다가 밖으로 빠져 나오면서 평수위로 올려 징그는 기법을 사용 하여 평수와 자연스럽게 연결되면서 장식하는 효과 를 나타내기도 하였다. 영지의 잎이나 화염 등에는
긴땀 평수를 놓고 그 위에 연채사를 징금하여 올려 서 엽맥 등을 입체감있게 표현하였다. 이 같이 징금 수에 연채사를 사용하는 기법은 후대의 자수에서는 많이 사용되지 않는 특별한 표현이다.

\section{5) 속수}

용의 비늘부분을 입체감 있게 표현하기 위해서 사용된 기법이다. 표면의 연금사가 소실된 부분에 서 속수가 확인된다. 용의 비늘을 표현할 부분에 굵은 면사를 사용하여 일정한 간격으로 성근 홈질 을 하여 면을 메웠다〈Fig. 23〉.

속수 위에는 먹으로 비늘모양의 밑그림을 그린 것이 확인된다. 금사는 면사와 반대방향으로 가지 런히 놓고 홍색 반푼사로 비늘모양을 따라 이음수 처럼 징거서 용의 비늘을 표현하였다〈Fig. 24〉. 이

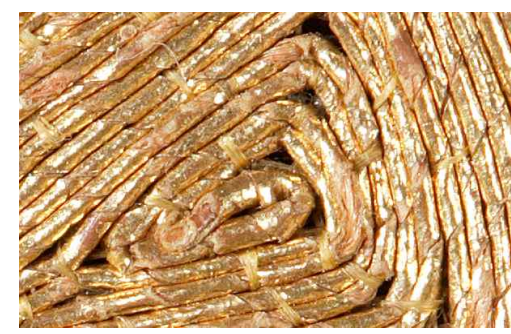

〈Fig. 20〉 Couching Stitch on Rapped Gold Thread (Photography by Researcher)

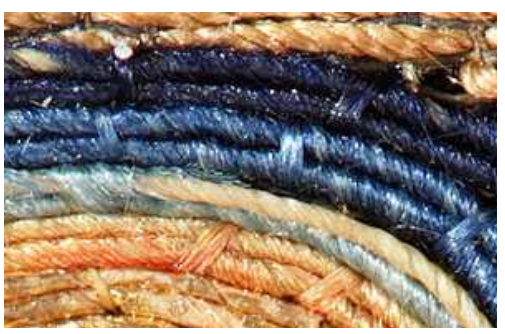

〈Fig. 21〉 Couching Stitch on Rapped Silk Thread

(Photography by Researcher)

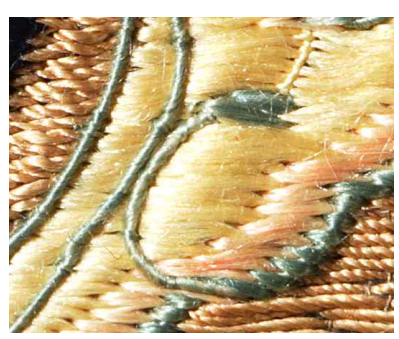

〈Fig. 22〉 Couching Stitch on Rapped Silk Thread (Photography by Researcher)

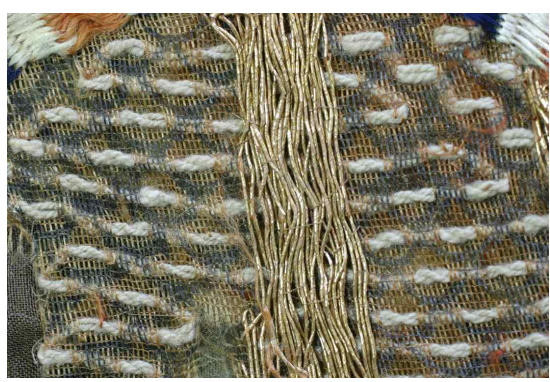

〈Fig. 23〉 Cotton Thread Padding

(Photography by Researcher)

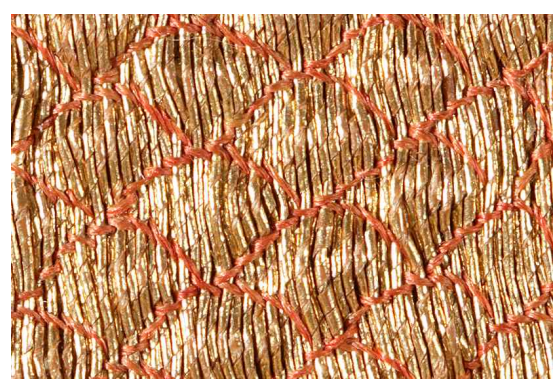

〈Fig. 24〉 Couching Stitch with Rapped Gold Thread (Photography by Researcher) 
음수로 눌러주지 않은 부분은 속수의 부피 때문에 볼록 튀어나와 용의 몸체를 양감 있게 표현하였다.

\section{6) 붙임수}

탁의 상단덮개는 매우 특별한 장식기법을 사용 하였다. 하단의 자수기법으로 표현된 좌용과 행용, 구름의 자수부분을 오려서 운보문단 바탕직물 위 에 붙이고 둘레를 꿰매어 고정시켰다〈Fig. 25〉. 바 느질은 홈질 또는 감침질을 사용했으며 매우 거칠 다. 이와 같은 장식기법은 서양의 아플리케에 해 당되며 중국에서는 첩수(貼繡)(Zhao, 1999)라고 하여 자수의 기법에 포함시키기도 한다. 본 연구 에서는 붙임수라고 명칭하였다.

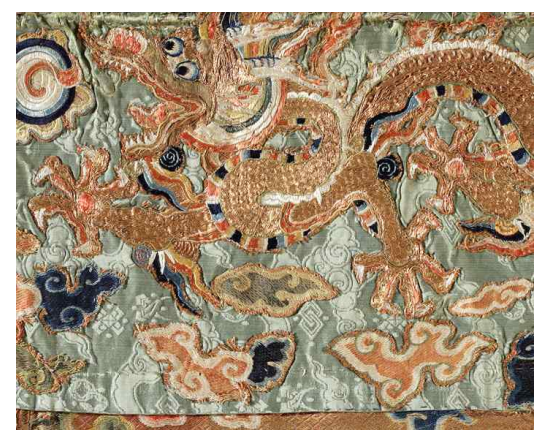

〈Fig. 25〉 Applique (Photography by Researcher)

\section{3. 자수기법의 시대적 특징}

탁의의 자수와 같은 납사수의 기법으로 가장 이 른 연대의 유물은 명대 신종만력(神宗万力, 1573 1620 )황제의 능인 정릉(定陵)에서 찾아 볼 수 있 다. 정릉 출토복식 중 〈수백자암화라방령여협의 (繣百子暗花羅方領女夾衣) $>$ 는 포 전체 바탕을 마 름모형 납사수로 놓은 대표적인 예이다. 이외에도 전세유물로 다수의 납사수 흉배가 전해지고 있다. 뉴욕의 메트로폴리탄 박물관에 소장되어 있는〈자 수봉라사녀(刺繡捧螺仕女) >는 중국 명대의 유물로 납사수로 마름모형 지문을 만들고 평수로 사녀의 주체를 수놓고 다시 금사와 채사(彩絲)를 둘러 문 양의 윤곽을 나타내고 있다.

국내소장 유물로는 한국자수박물관 소장된 〈기 호산신도(騎虎山神圖)〉〈Fig. 26〉가 있다. 용문자수 탁의와 마찬가지로 사직물 바탕에 납사수로 마름 모형 지문과 운문을 만들고, 평수로 산신과 꽃을 수놓았으며 호랑이는 징금수로 나타내었다. 수파 는 평수와 가름이음수로 표현하였다. 〈Fig. 27〉과 같이〈기호산신도〉의 바탕직물은 2경꼬임 사직물 을 사용하고 있으며, 두록색 꼰사로 마름모형 납

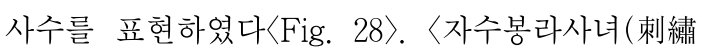
捧螺仕女)〉와〈기호산신도(騎虎山神圖)〉 모두 탁 의에 사용된 자수사의 특징과 자수기법이 동일함 을 확인할 수 있다.

또한 단국대학교 석주선 기념박물관 소장품 가

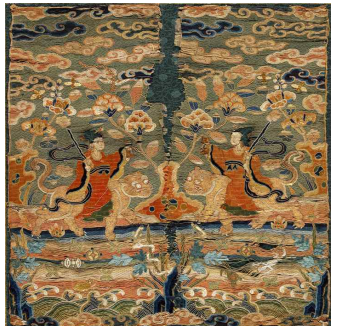

〈Fig. 26〉 Femail Figure Rriding a Tiger (Photography by Researcher)

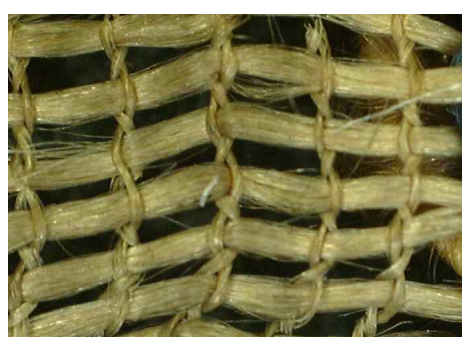

〈Fig. 27〉 Gauze Ground of Femail Figure Rriding a Tiger (Photography by Researcher)

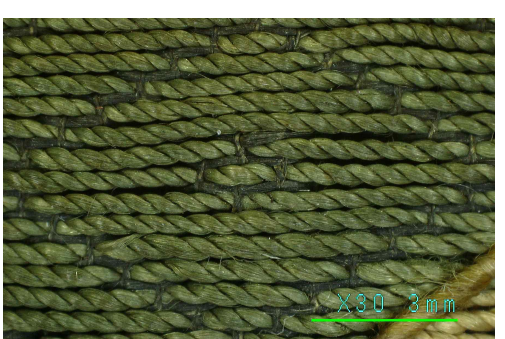

〈Fig. 28〉 Napssa - su of Femail Figure Rriding a Tiger (Photography by Researcher) 
운데 1987년 경기도 여주에서 출토된 동래정씨 정 태제(1612-1669년)의 유물 중 금사쌍학흥배 바탕 도 동일한 마름모형 납사수로 되어있다.

이상에서 살펴본 바와 같이 마름모형 납사수가 유행한 시기는 만력황제 출토유물과 정태제의 흥 배 등을 감안한다면 1500 년대 말에서 1600년대로 추정해 볼 수 있다. 이로서 용문자수탁의의 직물과 자수도 1600 년대에 제작되었을 것으로 추정된다.

\section{IV. 문양을 통해 본 탁의 제작과 시기}

탁의의 주체를 이루는 문양은 용, 구름, 수파문 이다. 용문은 강용(降龍), 좌용(坐龍), 행용(行龍) 등이 묘사되었으며 모두 5 조룡이다. 용이 배치된 공간 전체에는 오색운문이 충전되어 있으며 용문 의 하단에는 수파와 바위산으로 이루어진 강애해 수문(Sim, 2006)이 표현되었다. 탁의 하단 몸판은 11 조각의 자수직물〈Fig. 29〉을 이어서 문양을 구 성하고 있다. 탁의를 배설했을 때 중앙에 오는 부 분은 성수만년(聖壽萬年)을 상 - 좌·우로 배치하 였다.

〈Fig. 29〉의 1, 2, 4번째 폭의 용은 하늘에서 내 려오는 강용의 모습으로 꼬리를 위로 하고 몸통이 길게 내려오며 머리를 치켜들고 있다. 1 번 폭의 강용은 2 마리가 여의주를 사이에 두고 마주보고 있다. 2 번과 4 번 폭의 강용은 1 번 강용에 비해 크
며 단독으로 묘사되고 여의주는 용의 머리 위로 배치했다. 〈Fig. 29〉의 3번 폭에는 좌 - 우 · 하 에 네발을 좌우로 뺃고 앉아 있는 형상의 좌용이 삼면으로 배치되었으며 머리를 중앙으로 맞대고 있다. 각각의 좌용 머리 위로는 영지문과 함께 수 만년(壽萬年)이라는 명문이 자수되어 있다. 좌 우측의 용은 옆을 바라보고 하측 용은 정면을 향 하고 있다. 이 정면형 좌용은 〈Fig. 29〉의 d와 같 이 상반신만 남아있는데 이를 1 번째 폭 상단의 〈Fig. 29〉c의 하반신만 묘사된 좌용과 맞추어 보 면 같은 용임을 확인할 수 있다. 따라서 원래 1 번 폭은 3 번 폭 아래에 연결되어 있었음을 알 수 있 다. 상단덮개 녹색운보문단에는 걸어가는 모습의 행용 4 마리가 부착되어 있으며 다른 용문에 비해 서 작게 표현되어 있다. 행용이외에도 상단덮개 좌측 $(\mathrm{A}$ 폭)과 우측( $\mathrm{B}$ 폭)에 상하가 나누어진 좌용 의 형태가 있으며, $\mathrm{A}$ 폭의 $a$ 와 $\mathrm{B}$ 폭의 $\mathrm{b}$ 를 합성해 본 결과 같은 용의 부분임을 확인할 수 있었다.

3 번 폭의 $9,10,11$ 은 작은 조각을 이어 붙였는 데 원래 이 자리에 상단의 좌용 $(\mathrm{a}$ 와 $\mathrm{b}$ 를 합친 용) 이 배치되어 있었으며 성(聖)자는 좌용의 머리 위 로 자수되어 있었을 것으로 추정된다. 탁의를 구 성하면서 구성상 좌용을 위로 올리고 성자를 바로 세워 붙였을 것으로 추정하였다. 용이 있던 자리 는 바위와 파도문으로 대체했다.

탁의에 보이는 용문과 강애해수문은 중국 명대

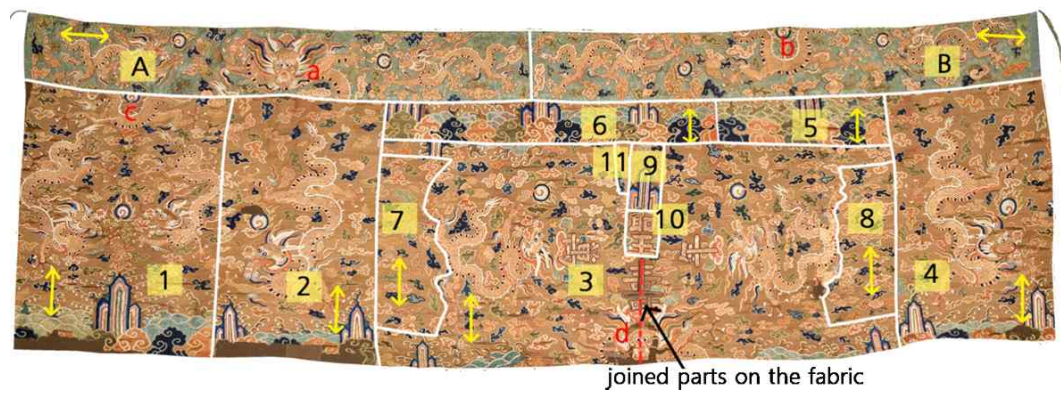

〈Fig. 29〉 Composition of Tak Ui with Dragon Pattern (Photography by Researcher) 
용포에서 보이는 형식이다. 명대 만력황제의 능에 서 출토된 복식 중에는 탁의의 용문과 구도가 유 사한 형식이 확인된다. 〈Fig. 30〉은 정릉에서 출토 된 〈직금장화용란직신용포료(織金妝花龍襴直身龍 袍料) >의 무늬를 재구성한 것이다. 목선을 중심으 로 좌용을 십자형으로 양 어깨와 앞면, 뒷면에 배 치하였으며, 뒷길 좌용 아래에는 마주보는 승용과 강애해수문을 묘사하였다. 뒷길에서 안쪽으로 들 어가는 좌·우측 폭에는 단독의 승용이 배치되었 으며 뒷길의 승용에 비해 몸집이 크다. 뒷길과 앞 길 하단에는 마주보는 행용이 묘사되어 있다.

탁의를 용포의 문양구성과 대비시켜 배치해 보 면〈Fig. 31〉과 같이 용의 형태나 구도가 거의 일 치함을 알 수 있다. 〈Fig. 29〉의 탁의 3번 폭과 1 번 폭을 연결하여 상하를 바꾸어 배치하면 앞길과 뒷길이 되고, 2 번, 4 번 폭은 뒷길 좌우 안쪽 폭이 되며, 상단의 행용은 앞길과 뒷길 하단부분의 단 과 일치함을 알 수 있다. 또한 5 번과 6 번의 강애 해수는 3 번 폭 좌용 아래에 배치되었을 것으로 본 다. 따라서 탁의는 명대 용포용으로 제작된 자수
품이었음을 확인하였다

중국의 용포용 직물을 탁의에 사용한 예는 통 도사에 소장된 대웅전 용문탁의에서도 살펴볼 수 있다. 용문탁의는 청대의 용포용으로 제직된 직성 필료(織成匹料)를 여러 폭 이어 탁의로 제작하였 다. 선암사 용문자수탁의도 구성된 직물들이 온 폭을 사용하고 있는 것으로 보아 용포용으로 제작 된 자수직물을 사용하였을 가능성이 있다고 보나 추후 좀 더 세심한 분석이 필요하다.

용포용 자수품을 탁의로 구성한 시기는 자수제 작시기보다는 조금 후대로 추정된다. 탁의는 하단 몸판과 상단덮개가 대비되는 색으로 표현되기 때 문에 탁의를 구성하면서 상단덮개로 녹색의 문단 직물을 별도로 구성하고 그 위에 하단과 동일한 자수를 오려 붙여 하단몸판과 통일감을 주었다. 탁의로 구성하면서 사용한 녹색운보문단〈Fig. 32〉 의 무늬는 무리구름문[骨梁雲] 에 잡보문이 일정하 게 배치된 형태로 양쪽에 꼬리를 달고 아래 위 운 문이 와운(臥雲)에 의해서 연결된 형태이다. 운두 가 작아지며 와운이 길어지는 형식에 서보, 서각,

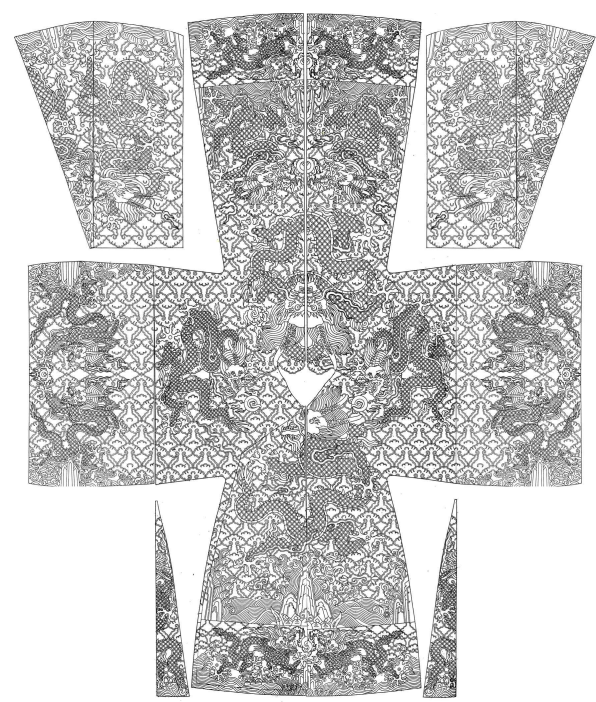

〈Fig. 30〉 Pattern of Ming Dynasty Dragon Robes

(The Institute of Archaeology, 1990, p. 47)

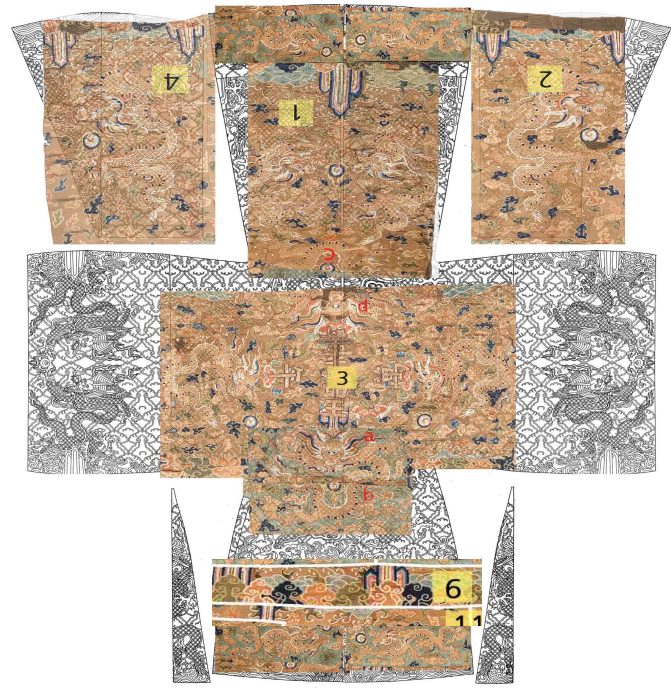

〈Fig. 31〉 A Comparison of Tak Ui Pattern and Ming Dynasty Dragon Robes (Illustration by Researcher) 


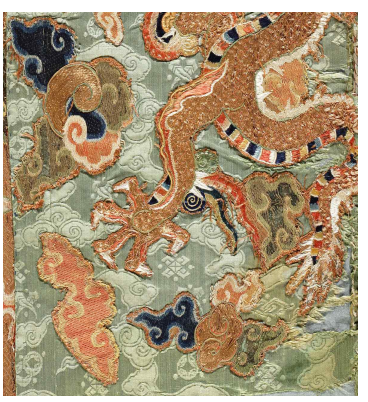

〈Fig. 32〉 Cloud Pattern of Tak Ui (Photography by Researcher)

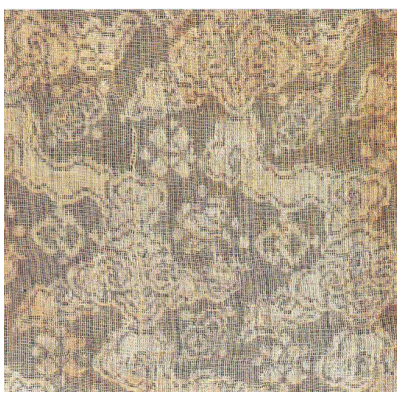

〈Fig. 33〉 Cloud Pattern (National Folk Museum of Korea, 2010, p. 162)

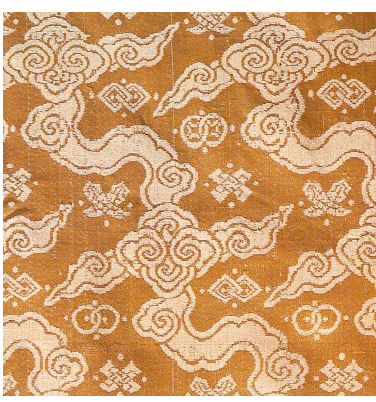

〈Fig. 34〉 Cloud Pattern (Dankook University Suk Joo-Sun Memorial Museum, 2001, p. 57)
전보, 방승, 옥보 등의 보문이 삽입되었다. 이와 같은 운보문의 유형은 이진숭(1702 1756)묘 출토 직령포의 운문〈Fig. 33〉, 풍산 홍씨 희준(羲俊, 1761 1841)의 묘 출토 운문〈Fig. 34〉등 1700년대 출토유물에서 보이며, 운문의 형태, 구도 및 보문 의 종류와 표현법이 거의 흡사하다.

따라서 탁의가 용포용 자수로 만들어 진 시기 는 1600 년대 명대이며, 탁의로 구성된 것은 1700 년대일 것으로 판단된다.

\section{$\mathrm{V}$. 맺음말}

선암사에 소장된 〈자수용문탁의〉에 대해 구성, 직물, 자수기법, 문양 등을 조사- 분석하여 섬유학 적 특징과 제작시기 등을 살펴보았다.

탁의는 불교 사찰에서 불탁을 덮거나 둘러서 치 는 장엄구의 하나이다. 회화와 유물에 나타난 탁의 구성은 몸판과 상단의 덮개, 영자로 이루어져 있 다. 몸판은 대개 붉은색이며 상단은 녹색, 청색을 사용하며, 드물게 몸판을 초록색, 상단을 붉은색으 로 하는 예도 있다. 용문자수탁의는 다른 탁의의 구성형식과는 다르게 몸판과 상단덮개가 바느질되 어 일체형으로 만들어졌으며 영자도 없다.

탁의의 몸판은 무늬가 없는 2 경꼬임의 사직물 바탕에 전체가 자수로 조성되었으며 5폭을 이어
만들고, 그 외 작은 조각 10 여 편을 이어 붙여 문 양을 구성하였다. 상단은 가로방향의 녹색운보문 단 2폭을 이어서 만들고 그 위에 자수를 잘라 붙 인 매우 독특한 형식이다.

자수에는 견꼰사, 견푼사, 연금사, 연채사를 사 용하였으며 용 비늘 부분의 입체감을 위해 면사로 속수를 놓았다. 자수기법은 납사수, 평수, 징금수, 가름이음수, 이음수, 붙임수 등이다.

가장 특징적인 자수는 탁의 지문으로 놓여 진 납사수로서 사직물 바탕에 규칙적으로 올을 세며 자수하여 마치 직조와 같은 외형을 표현하였다. 납사수는 2가지 유형이 확인되며 규칙적으로 올을 떠서 마름모형 문양을 만들거나 직조의 조직점과 같은 표현을 하였다. 모두 표면수로 자수되었으며 가로방향으로 바탕조직의 위사와 위사 사이에 가 로로 놓여 마치 직조기법인 장화조직의 문위사와 같이 표현되었다.

가름이음수는 우리나라 자수에서는 처음보이는 형식으로 마치 사슬수와 같이 표현되었으며 평수 위에 수를 놓아 긴 땀을 눌러주는 역할과 더불어 장식적인 효과를 나타내었다. 연채사는 꼰사를 심 사로 하여 푼사를 말아 감아 만든 장식적인 실로 써 각색으로 주체문양의 가장자리에 두르거나 징 거서 장식하였다. 후대의 자수에서는 볼 수 없는 독특한 기법이다. 
납사수 바탕에 주제문양을 평수, 금사징금수, 연채사징금수, 가름이음수 등으로 표현하는 자수 법은 중국명대의 특징적인 형식으로 흥배 등의 전 세유물로 많이 남아있다. 탁의에 보이는 용문과 강애해수문은 중국 명대 용포에서 보이는 전형적 인 구성의 하나이다. 명대 만력황제의 능에서 출 토된 용포의 문양과 비교해 본 결과 용의 유형과 구성 등이 유사하여 용문자수탁의는 원래 명대 용 포용으로 제작된 자수품이었을 것으로 판단하였 다. 따라서 용문자수탁의의 직물과 자수가 제작된 시기는 1600 년대로 추정하였다.

용포용 자수품을 탁의로 구성한 시기는 탁의 상단에 덧댄 녹색운보문단이 1700 년대 유행한 형 식인 점을 고려하여 18 세기로 추정하였다.

용문자수탁의가 선암사에 소장된 연유는 정확 하지 않다. 영조 12년(1736)에 조성된 선암사 감 로탱에 나타나는 탁의의 모습이 주황색바탕에 녹 색의 상단을 두르고 있어 용문자수탁의의 구성과 흡사하다. 따라서 선암사 소장 시기는 1600년대 말에서 1700년대 초로 추정해 볼 수 있다.

용문자수탁의는 중국과 외국에 남아 있는 명대 의 납사수 작품 중에서도 찾아보기 힘든 대작의 자수이며 자수기법과 색채 등이 잘 보존되어 있어 동아시아 자수 연구 및 복식 연구에 큰 중요성을 지닌다.

\section{References}

Dankook University Suk Joo-Sun Memorial Museum. (Ed.) (2001). Textile Patterns in Joseon Dynasty. Seoul, Republic of Korea: Dankook University Press.

Heo, S. H. (2004). The buddhist altar of the late Joseon period, Korean Journal of art history, 244(5), 121-170. Kang, W. B. \& Kim, S. H. (2010). The World of Nectar Ritual Painting. Seoul, Republic of Korea: Yekyong.

National Folk Museum of Korea. (2010). Costumes Excavated from Yi,Jin-sung's tomb. Seoul, Republic of korea: National Folk Museum of korea.

Sukjong Silok [ 肅宗實錄] (1696).

Sim, Y. O. (2002). 5,000 Years of Korean Textiles,
Seoul, Republic of Korea: ISAT.

Sim, Y. O. (2006). 2,000 Years of Korean Textile Design. Seoul, Republic of Korea: ISAT.

Sim, Y. O. (2013), Study on Fabric and Embroidery of 〈Embroidered Screen with Grass and Insects〉. Korean Journal of Cultural Heritage Studies, 46(3), 230-251.

The Institute of archaeology. CASS, Museum of Ding Ling \& The archaeological team of the city of Beijing. (1990). Ding Ling[定陵]. Beijing, Republic of China: The Institute of archaeology Press.

Zhao, F. (1999). Treasures in Silk. Hong Kong, People's Republic of China: ISAT. 